\title{
Financial Services and Markets Act: market abuse
}

by Charles Abrams

The new civil offence of market abuse - introduced by the Financial Services and Markets Act 2000 (FSMA 2000) - is explained in the following piece.

\section{THE 'CIVIL' OFFENCE OF MARKET ABUSE}

One of the important differences between the Financial Services Act 1986 (FSA 1986) and the FSMA 2000 is the introduction in the latter of the new civil offence of market abuse. The term 'civil offence' is used because this is how the government describes market abuse. Importantly, the penalty for market abuse, which is policed and enforced by the Financial Services Authority (FSA), is an unlimited fine or public censure and an unlimited obligation to surrender any resulting profits and to compensate everyone who has suffered any resulting loss (see FSMA 2000 s. 118 - s. 131). The unlimited fine seems to make it a criminal offence and, indeed, the government has accepted that there is a 'real possibility' that it would be treated as a criminal offence for the purposes of the European Convention on Human Rights (ECHR). The government has therefore provided some (but arguably not all) of the procedural protections which the ECHR requires in the case of proceedings for a fine.

\section{WHAT IS THE OFFENCE OF MARKET ABUSE?}

There are three different offences of market abuse:

(1) misusing information which is not generally available to the relevant market;

(2) misleading the market; and

(3) distorting the market.

However, behaviour will not constitute market abuse unless it is likely to be regarded by a reasonable 'regular user' of the market concerned as a failure on the part of the putative abuser to 'observe the standard of behaviour reasonably expected of a person in his position in relation to the market'. This condition is likely to prove to be very helpful to 'market innocents' who would otherwise unwittingly commit the offence.

In addition, another 'market abuse' offence is committed by somebody who requires or encourages someone else to commit the offence (see FSMA 2000 s. 118).

\section{WHO COULD COMMIT THE OFFENCE?}

The offence of market abuse can be committed by anyone, and not just by FSMA 2000-authorised firms. In fact, given that the FSA can also impose unlimited fines on firms regulated by it for failing to live up to the standards required by the two FSA principles (that they must conduct their business with integrity and must observe proper standards of market conduct), it is likely that market abuse 'prosecutions' will more often be brought against firms which are not FSMA 2000-authorised. This is one of the reasons why the government introduced the offence of market abuse.

Importantly, market abuse can be committed even without intent to abuse the market at all. In addition, it applies to all transactions in the prescribed quoted securities, even if they are over-the-counter (OTC) transactions. In fact it does not need any transaction at all. Melanie Johnson MP, the Economic Secretary to the Treasury, made it clear during the debates in Committee in the House of Commons that issuing a misleading press release could constitute market abuse. Accordingly, not only securities houses and banks but also directors of quoted companies need to be aware of the offence.

\section{RELATIONSHIP WITH CRIMINAL OFFENCES}

The offence of market abuse is based on the existing criminal offences of insider dealing (contained in Pt. V of the Criminal Justice Act 1993) and market manipulation (currently in s. 47 of the Financial Services Act 1986 and replicated in s. 397 of the FSMA 2000). The two criminal offences will continue and in many cases their exemptions will not apply to market abuse.

The FSMA 2000 contains a provision allowing the Treasury to issue written guidance as to when prosecutions should be brought for the civil offence rather than the criminal offences. Indeed, the FSA is empowered by the Act to bring prosecutions itself for insider dealing and market manipulation. 
It is to be hoped that the rules against double jeopardy will prevent insider dealing or market manipulation prosecutions being brought if a market abuse prosecution fails and, of course, the reverse. The UK rule against double jeopardy may not apply, because market abuse is technically a civil offence. However, the ECHR outlaws double jeopardy for criminal offences. Although the relevant provision has not been included in the Human Rights Act 1998, one hopes the government will regard it as applying, because it has decided to treat market abuse as a criminal offence for ECHR purposes (see ECHR, Protocol 7, art. 4). In addition, the similar UK doctrine of autrefois acquit may apply.

\section{WHAT AMOUNTS TO ABUSIVE BEHAVIOUR?}

Market abuse is defined as 'abusive' behaviour which 'occurs in relation to qualifying investments traded on a market to which this section applies' (s. 118(1)(a)) Qualifying investments are to be prescribed by the Treasury, which is also responsible for designating the markets subject to the 'market abuse' regime. This restriction to behaviour 'in relation to' the qualifying investments is, however, not quite as limiting as it seems.

First, 'behaviour' expressly includes inaction as well as action, and therefore even a failure to do something can constitute market abuse; perhaps a typical example would be failing to disclose the acquisition or disposal of an interest in shares under s. 198 of the Companies Act 1985.

More importantly, behaviour is to be regarded as occurring in relation to qualifying investments if it occurs in relation to anything which is the subject matter of the qualifying investments or which occurs in relation to investments whose subject matter is those qualifying investments. Typically, this covers behaviour relating to commodities the subject of futures contracts traded in London, for example, on the London Metal Exchange. It also covers behaviour relating to, for example, options on investments quoted on the London Stock Exchange.

In addition, and importantly for non-UK firms, behaviour can constitute market abuse not only if it occurs in the UK but also if it occurs anywhere else in the world. The only proviso is that the investments in relation to which it occurs (on this wide definition) are traded on a designated market which is situated in the UK or which is accessible electronically from the UK. Accordingly, if a dealer in New York grants a dealer in Hong Kong a put option over shares quoted on the London Stock Exchange, his behaviour is, in relevant circumstances, capable of constituting market abuse.

Indeed, if the Treasury designates either NASDAQ or EASDAQ, which although non-UK exchanges are accessible electronically from the UK, the offence can be committed in relation to securities quoted on them by behaviour anywhere in the world. It should perhaps be noted that, in mid-July 2000, the Treasury designated EASDAQ as a regulated market subject to the insider dealing provisions of the Criminal Justice Act 1993 and that NASDAQ has always been a regulated market subject to them. (See Insider Dealing (Securities and Regulated Markets) Order 1994, SI 1994/187; Insider Dealing (Securities and Regulated Markets) (Amendment) Order 2000, SI 2000/1923).

\section{'INNOCENT' MARKET ABUSE}

As indicated, the offence of misleading the market can be committed without any intent to mislead the market at all. Several attempts were made (for example, by the London Investment Banking Association (the LIBA), the Confederation of British Industry (the CBI), APCIMS and the Conservative Party's Treasury Team) to persuade the government that it would be unfair to penalise people who had no idea that what they were saying or writing could be misinterpreted. However, the government stressed that market abuse is an effect-based offence and not an intentbased offence and, because a market could be prejudiced even by behaviour which was merely negligent, refused to bring in an intent element. One unfortunate consequence of this is that behaviour can constitute misleading the market even if the firm did not anticipate that what it said or wrote was misleading; this, moreover, is often not true negligence.

The government did agree, however, that it should be a quasi-defence for the accused person to show that he believed, on reasonable grounds, that his behaviour did not constitute market abuse or the requiring or encouraging of market abuse or, alternatively, that he took all reasonable precautions and exercised all due diligence to avoid committing any of these offences. This is helpful but it seems to require the accused person actually to have thought about market abuse. In addition, although the defence helpfully stops the FSA imposing a fine (or, seemingly issuing a public censure) or requiring compensation or a surrender of profits, it still leaves the behaviour as constituting market abuse (which is why it is only a 'quasi-defence'). This may have consequences for FSMA 2000-authorised firms or their employees but possibly not for anyone else.

The FSA is also directed by the FSMA 2000, although not in so many words, to impose a lesser penalty if the behaviour was not deliberate or reckless. The Conservative Party's Treasury Team tried to amend this provision to read that the 'market abuse' was not deliberate or reckless but the government maintained its position (although one hopes that this was not because it wanted to restrict the smaller fine to mere accidents). The government also refused to allow the FSA the discretion to take into account the fact that the 'abusive' behaviour conformed with existing market practice. (See FSMA 2000 s. 123 on powers to impose penalties in cases of market abuse, and s. 124 (statement of policy)). 


\section{COMPLYING WITH THE FSA'S CODE OF MARKET CONDUCT}

The FSA is required by the FSMA 2000 to issue a code containing guidance on whether particular behaviours amount or do not amount to market abuse (s.119). In July 2000 it issued a second draft of its proposed 'Code of Market Conduct'. The FSA can only explain the offence of 'market abuse' and not change it. Within that constraint, however, it has clearly tried to be as fair and reasonable as possible and has indicated that it is primarily worried about market abuse which is intentional. The draft Code also provides that activities within specified exemptions from the criminal offences of insider dealing and market manipulation will not be contrary to the Code. In both cases, the behaviour can, however, still constitute the statutory offence. Nonetheless, the draft Code seems to indicate that the FSA will not impose a fine if there was no intent, although it may still require compensation and a surrender of profits.

Unfortunately, firms cannot assume that behaviour conforming with the Code will necessarily be outside market abuse. The FSMA 2000 makes it quite clear that the Code is evidential only, unless the FSA states expressly that, in its opinion, the particular behaviour does not amount to market abuse. When the Bill was in the House of Commons, the government accepted that compliance with the FSA's conduct of business rules should not constitute market abuse. However, the government subsequently restricted the safe harbour in the Lords and it is now provided that conformity with an FSA rule will not constitute market abuse only if the rule contains a provision to the effect that conforming with it does not amount to market abuse. Accordingly, FSMA 2000authorised firms can be put in the ridiculous position of having to choose between complying with the FSA's rules and possibly being subject to an unlimited fine for market abuse, or other avoiding possible market abuse and being subject to an unlimited fine for failure to comply with FSA rules.

The government similarly refused any safe harbour at all for behaviour conforming with the rules of recognised investment exchanges (RIEs), even though it was emphasised to the government that the FSA could ensure that the rules of RIEs did not require anything to be done which could constitute market abuse. The FSA's draft Code of Market Conduct, however, indicates that the FSA will nonetheless provide safe harbours for compliance with at least some specified RIE rules.

It is difficult to see how any market abuse (typically, insider dealing or issuing a misleading statement in a press release or prospectus) can ever be 'required or expressly permitted' by FSA or RIE rules, which is how the draft Code quite properly defines 'conforming with', and these safe harbours may therefore not be very helpful in practice.

\section{MARKET ABUSE IN THE COURSE OF A TAKEOVER BID}

The government has insisted that the FSA should have jurisdiction over alleged market abuse even if it occurs in the course of a takeover bid. Although the government acknowledged the reputation of the Takeover Panel and has sought to preserve the self-regulatory status of the Panel, despite the forthcoming EU directive on takeovers, it was insistent that the FSA should have the ultimate say on whether market abuse did or did not occur. The FSA has, however, announced that it would, 'as a rule', not intervene during a bid where the Panel can itself take 'adequate action' to deal with the market abuse and that it would always liaise with the Panel before intervening.

Although the government suffered defeat in the Lords on this issue, the FSMA 2000 now contains a provision that the FSA may include in its Code of Market Conduct provision to the effect that behaviour conforming with the Panel's Takeover Code does not amount to market abuse in particular circumstances). However, such was the government's concern about all this that the FSMA 2000, exceptionally, prohibits the FSA from including any such provision without the approval of the Treasury. The FSA announced in the consultation paper accompanying the draft Code of Market Conduct (which does not contain any safe harbour for behaviour during takeovers) that it was indeed discussing possible safe harbours with the Panel and would soon issue some for consultation.

The FSMA 2000 also imposes on the FSA a statutory duty to keep itself informed of the way in which the Panel interprets and administers the 'safe harbour' provisions of the Takeover Code. The government justified this on the basis that the FSA would as a result apply the same interpretation as the Panel. However, it seems that this statutory duty in effect constitutes a 'Sword of Damocles' that will always be hanging over the Panel in case the FSA does not agree with the Panel's interpretation and consequently decides to withdraw the safe harbour. It will therefore be prudent for the Panel to make sure that its interpretations of the 'safe harbour' provisions are always approved in advance by the FSA. (See FSMA 2000 s. 120 (provisions included in the Authority's code by reference to the City Code) and the proposed Thirteenth EC Company Law Directive on Takeovers (COM(97)565)).

\section{Charles Abrams}

Partner, SJ Berwin \& Co

Charles Abrams is co-author of The Guide to Financial Services Regulation, 3rd edition, $\mathrm{CCH}$.

This article is taken from 'A short guide to the Financial Services and Markets Act 2000', which has been published as a special report with the Financial Services Reporter, CCH. 